\title{
Effect of Cow and Goat Urine against Dominant Myco-Toxin Producing Fungi
}

\author{
Sonam Kumari ${ }^{1}$, Shrvan Kumar ${ }^{2}$, Vishal Srivashtav ${ }^{1}$ and Pardeep Kumar $^{3}$

 \\ Mirzapur, U.P. - 231001, India \\ ${ }^{2}$ Department of Mycology and Plant Pathology, RGSC, B.H.U., Barkachha, \\ Mirzapur, U.P. - 231001, India \\ ${ }^{3}$ KVK, Sohna (NDUA\&T, Ayodhya), Siddhartha Nagar, U.P., India \\ *Corresponding author
}

\section{A B S T R A C T}

The groundnut value chain in world employs a significant number of people, thereby contributing substantially to the economy. This groundnut cultivation

Keywords

Groundnut, Cow and Goat urine, Aspergillus flavus, A. niger and P. chrysogenum

Article Info

Accepted: 12 May 2021 Available Online: 10 June 2021 has a direct positive impact on uplift of nutritional and economic status of smallholder farmers. The groundnut is cultivated in more than 100 countries under different agro-climatic conditions. Plants of groundnuts are highly susceptible to fungal contamination, including toxin producing fungi. However, toxicogenic fungal species are important constraints to the production the crop, affecting the quality of the seeds during storage. Antifungal activity of different per cent concentrations $(5,10,25$ and 50) of cow/goat urine against mycotoxin producing fungi i.e., Aspergillus flavus, A. niger and $P$. chrysogenum were recorded through poisoned food technique. The maximum mycelium growth inhibition of three tested fungi were showed in goat urine based on fresh and dry weight of mycelium due to the goat eat lots of medicinal plants. Components of medicinal plants in goat urine showed antimicrobial properties i.e. inhibits the mycelial growth of fungus.

\section{Introduction}

Groundnut (Arachis hypogea L., $2 \mathrm{n}=20$ ), also known as peanut is the major legume crop grown globally. It was primarily originated in South America; due to large amenability and high output capacity it is fully-fledged over a broad geographical range. In many lowincome countries of Asia and Africa, the crop is primarily grown for subsistence by smallholder farmer, predominantly women, under rain-fed and low input conditions and 
thus account up to $50 \%$ of total cash crop production (Ojiewo et al., 2020). The groundnut is cultivated in more than 100 countries under different agro-climatic conditions on about 26.5 mha with a total production of $43.9 \mathrm{mt}$ and productivity of $1654 \mathrm{Kg}$ ha-1 (FAO, 2017). As of 2018, China is the largest producers of peanuts worldwide, holding an estimated $40 \%$ share of global production. India ranked second that year, producing about $15 \%$ of the world's peanuts. In India, Gujarat is the top region for production of groundnut. As of 2017, production in Gujarat was 3.16 million tonnes that accounts for $42.30 \%$ of India's groundnut production. Other than Gujarat; Maharashtra, Andhra Pradesh, Tamil Nadu, Karnataka and Rajasthan are top 5 region which account $80.72 \%$ of it (Shahbandeh, 2020).

On the advent of promising circumstances lots of seeds were perpetuated through firm parasitic micro-organisms and saprophytes or they interrupted their enzymatic pathway. During Pre-harvested and Post-harvested period, groundnut seeds are highly susceptible to fungi such as Aspergillus (fumigatus, niger, flavus), Penicillium spp., Rhizopus spp., Rhizoctonia spp., Fusarium spp. (Dharmaputra, 2003; Craufurd et al., 2006). Seed-borne mycoflora reduce the yield of crop plants both quantitatively and qualitatively and may cause seed necrosis, reduce germination potential and seed rot causing development of disease by local or universal infection (Kumar, 2015a).

As we know, many species of fungi are economically important they are decomposers, saprotrophs and play diverse role in their own way. Most of them are poisonous and producing significant mycotoxins. Several harmful or life-threatening impacts on consumers, such as loss of human and animals' lives; health care, veterinary care costs; contaminated foods and feeds disposal costs; and investment in research and management of the mycotoxin's problems (Kumar et al., 2015a). Aflatoxins is also a very serious concern in India too. A recent study of ICRISAT revealed that In Southern India, the level of aflatoxins in peanuts may be 40 times higher than i.e., allowed by Indian food safety limits (Mausch, et al., 2017).

Mycotoxins are highly potent, lethal and induce diverse or powerful biological effects. Mycotoxins have diverse action on animal and human being, which has been characterization like - nephrotoxic, mutagenic, neurotoxic, carcinogenic, immunosuppressive, cytotoxic and oestrogenic effect (Kumar et al., 2015c).

The ultimate goal is to offer appropriate and efficient antimicrobial strategies to the plant. Focus on animal products used for their therapeutics abilities against microbes (Ghosh and Biswas, 2018). According to various health organization, animal products would be an appropriate source to obtain a variety of biopesticides, therefore such products should be investigated to understand their properties, safety and efficacy for a search of new potent antimicrobial/antifungal compounds (Raghavendra et al., 2020).

In Ayurveda, cow urine has unique place because it is secretion of animal origin with most effective substance and innumerable therapeutic value. Several medicinal properties of cow's urine have been mentioned (Ghosh and Biswas, 2018, Raghavendra et al., 2020) and are known to cause immunomodulatory, hypoglycemic and cardio-respiratory effects. Based on the literature search, it was hypothesized that medicinal properties of goat urine may be due to goat feeds many medicinal plants. Components of medicinal plants in goat urine showed antimicrobial properties and presence of some of the secreted antimicrobial peptides in the urine of goat. Thus, the present 
investigation was designed to show the effects of cow/goat urine on seed mycoflora of groundnut especially on fungus (Raghavendra et al., 2020).

\section{Materials and Methods}

Locally available cow (CU) and goat urine (GU) were used for testing their efficacy against Aspergillus flavus, A. niger and Penicillium chrysogenum at percentage concentration 5, 10, 25 and 50 preparing with potato broth medium- PBM. The concentration of cow and goat urine, 5 percent (CU-15ml+ PBM-285ml), 10 percent (CU$30 \mathrm{ml}+\mathrm{PBM}-270 \mathrm{ml}$ ), 25 percent (CU-75ml+ PBM-225ml) and 50 percent (CU-150ml+ PBM-150ml) were prepared in the flasks under aseptic conditions and sterilized in autoclave $15 \mathrm{psi}\left(121.6^{\circ} \mathrm{C}\right)$ for 15 minutes. The medium containing different concentrations of cow and goat urine was poured $(20 \mathrm{ml})$ in each sterilized Petri plates under aseptic conditions. Each Petri plate was inoculated with $10 \mathrm{~mm}$ mycelial disc cut with the help of sterilized cork-borer from 10 days old culture of test fungus and unamended plates served as check. Three replications were maintained for each treatment and incubated at $28 \pm 1^{\circ} \mathrm{C}$. Regular observations were recorded and finally mycelial mate was weighed 7 days after inoculation. By Vincent (1947) formula percent inhibition of mycelial growth was calculated as follow:

$\mathbf{I}(\%)=\frac{100(\mathbf{C}-\mathrm{T})}{\mathrm{C}}$

Where, I is inhibition percentage of mycelia growth, $\mathrm{C}$ is mycelial growth weight in control Petri plates, and $\mathrm{T}$ is mycelial growth in cow/goat urine in Petri plates. The data recorded in laboratory and experiments was statistically analysed by CRD design and the statistical significance at 5 per cent level was used for interpreting the data.

\section{Results and Discussion}

\section{On Aspergillus flavus}

The data on colony fresh, dry weight (in gm) and per cent growth inhibition studies in term of mycelial growth of Aspergillus flavus are accessible in (Table-1) Antifungal activity of cow and goat urine increased significantly with the increase in concentration of cow and goat urine. At 50 per cent concentration cow and goat urine resulted in 72.872 and 73.409 per cent inhibition of mycelial growth of $A$. flavus. However, at 25 per cent concentration goat urine gave maximum inhibition $(53.445 \%)$ followed by cow urine $(52.504 \%)$. goat urine and cow urine at the same concentration resulted in 15.455 and 11.667 per cent mycelial growth inhibition, respectively. Among the cow urine minimum inhibition of mycelial growth of A. flavus was observed at all the test concentrations. The maximum mycelial fresh and dry weight (in gm) of A. flavus was found in cow urine (6.110 and 2.077) followed by goat urine (6.049 and 2.036) at 5 per cent concentration. However, minimum mycelial fresh and dry weight (in gm) of A. flavus was found in goat urine (1.150 and 0.387) followed by cow urine (1.162 and 0.395$)$ at 50 per cent concentration. Per cent mycelial growth inhibition of $A$. flavus was observed based on dry weight ranges between 12.522-72.943 in cow urine and 15.455 to 73.851 in goat urine at all the test concentrations.

All the test cow and goat urine at 10 per cent concentration were mycelial growth inhibition 41.696 and 39.162 per cent of A. flavus. There is no available report on in vitro antifungal activity of cow and goat urine against $A$. flavus. However, antifungal activity of cow and goat urine against Colletotrichum falcatum has been reported by Modi, et al., 2017. These results indicate that cow urine (PDA-750 $\mathrm{ml}+$ Cow urine-250 $\mathrm{ml}$ ) 
expressively reduced the mycelial expansion even after 10 days of inoculation in valuation to cow dung (2\%) and goat urine (PDA-750 $\mathrm{ml}+$ Goat urine-250 $\mathrm{ml}$ ) and dung of goat (2\%) samples. Inoculated mycelial growth inhibition was diverting after 3, 5, 7 and 10 days before that period inhibition was neutral. After inoculation most of the treated activity show peak value after 5 days subsequently activity of cow urine was found to be reduced. In case of cow dung minimum mycelial growth showed at initial day after inoculation after that as days were proceeding activity progressively increased. Increased activity of cow urine may be due to desertion of some instable components from urine while least mycelial growth inhibition of cow dung shown at initial day after inoculation then after as day was proceeding activity was consecutively increased. As compared to cow urine and dung, goat urine and dung also show lesser extent of Mycelial growth inhibition respectively.

Thamamarai et al., (2019) were reported that results on the effect of combinations of animal excrements at $1: 1$ ratio $(\mathrm{v} / \mathrm{v})$ on the fungitoxicity against $P$. oryzae (both solid and liquid medium). Sheep urine combined with buffalo urine, cow and goat urine $(5 \%)$, hen litter (20\%), sheep dung (40\%) and buffalo urine combined with cow urine $(5 \%)$ were highly effective in inhibiting the mycelial growth of $P$. oryzae when compared to individual animal excreta treatments. Reinoculation in to fresh media did not revive their viability upon the inhibited disc and thus provided the fungicidal nature of animal excreta combination.

\section{On Aspergillus niger}

In vitro data on effect of cow and goat urine on the mycelial growth inhibition of $A$. niger presented in (Table- 2) indicated that all test of cow and goat urine significantly inhibited the mycelial growth over check. The maximum mycelial growth inhibition of $A$. niger was recorded in goat urine 66.845 followed by cow urine 66.175 at 50 per cent concentration. However, goat urine at 25 per cent concentration resulted in $49.437 \%$ mycelial growth inhibition followed by cow urine (48.416\%). Among the cow urine minimum inhibition of mycelial growth of $A$. niger was observed at all the test concentrations. The maximum mycelial fresh and dry weight (in gm) of A. niger was found in cow urine (5.216 and 1.773) followed by goat urine (5.163 and $1.738)$ at 5 per cent concentration. However, minimum mycelial fresh and dry weight (in $\mathrm{gm})$ of $A$. niger was found in goat urine (1.150 and 0.387 ) followed by cow urine (1.541 and $0.519)$ at 50 per cent concentration. Per cent mycelial growth inhibition of $A$. niger was observed based on dry weight ranges between 13.584-67.142 in cow urine and 16.481 to 68.243 in goat urine at all the test concentrations.

Darwin et al., (2020) in vitro studies were conducted to control the pathogen by using natural products viz., plant extracts, animal excrements and bio control agents. Among 10 commonly available botanicals, tested for their efficacy against $P$. grisea by poisoned food technique, the extracts of Azadirachta indica followed by Eucalyptus citrodora and Prosopis julifera were found to successfully inhibit the mycelial growth of the fungus.

Sheep urine at $10 \%$ concentration, buffalo urine and goat urine at 20 per cent concentration and cow urine at 30 per cent concentration recorded complete inhibition of $P$. grisea. However, goat dung and cow dung per cent mycelial growth inhibition of $P$. grisea were recorded 83.5 and 76.1 at same concentration. Among the various bio inoculants $P$. fluorescens followed by Serratia marcense recorded a growth inhibition of 85.8 $\& 79.0 \%$ respectively. 


\section{On Penicillium chrysogenum}

The results on behaviour of antagonistic of cow and goat urine on the mycelial growth inhibition of $P$. chrysogenum are presented in (Table- 3). The maximum mycelial growth inhibition $(66.137 \%)$ was achieved with goat urine followed by cow urine $(65.453 \%)$ at 50 per cent concentration. However, goat urine at 25 per cent concentration resulted in $43.811 \%$ mycelial growth inhibition followed by cow urine $(42.676 \%)$. Among the cow urine minimum inhibition of mycelial growth of $P$. chrysogenum was observed at all the test concentrations.

The maximum mycelial fresh and dry weight (in gm) of $P$. chrysogenum was found in cow urine (4.766 and 1.620) followed by goat urine (4.718 and 1.588) at 5 per cent concentration. However, minimum mycelial fresh and dry weight (in gm) of $P$. chrysogenum was found in goat urine (1.575 and 0.530) followed by cow urine (1.591 and 0.541) at 50 per cent concentration. Per cent mycelial growth inhibition of $P$. chrysogenum was observed based on dry weight ranges between 10.71566.440 in cow urine and 13.709 to 67.566 in goat urine at all the test concentrations.

Prakash and Sinha (2017) were using poisoned food technique under in vitro condition for the testing to the antifungal activity of cow urine against mycelial growth of Sclerotium oryzae. Radial growth of mycelium of $S$. oryza at concentration $2.5,1.5$ and 0.62 percent was 1.66, 32.66 and $50.33 \mathrm{~mm}$ recorded respectively. No mycelial growth was recorded at the concentrations of 5.0, 7.5 and 10.0 per cent. Cow urine at the concentrations of 5.0, 7.5 and 10.0 per cent were found highly effective against $S$. oryzae, whereas, cow urine at the concentrations of 2.5, 1.5 and 0.62 per cent resulted in 98.0, 63.7 and 44.07 per cent inhibition, respectively. Per cent inhibition at the concentration of 2.5, 1.5 and
0.62 per cent are statistically significantly different from control as well as they are also significantly different from each other.

Per cent inhibition at concentration 2.5, 5.0, 7.5 and 10.0 per cent are statistically at par with each other. Per cent inhibition of mycelial growth is more in cow urine as compared to A. cepa and A. sativum.

Ghosh et al., (2019) were test attempted to inconsistency of nearly some fungal pathogens of genera Aspergillus spp. (fumigatus, niger, flavus), Fusarium (verticillioides, fujikuroi), Penicillium spp., Macrophomina spp., Mucor spp., Alternaria spp., Rhizopus spp., with various percent concentrations $(20,40,50,70$ $\& 100$ ) of cow urine, all above pathogens were inaccessible from infested plant of Wheat. When compared to the control plate, the plate septic with cow urine was showing insufficient amount of test fungi growth. Cow urine show most operative effect at $100 \%$ concentrations among all above concentrations. So, it has been proved that the $\mathrm{CU}$ has antimicrobial activities and Finally, concluded that the inhibitory activities and antifungal activities of cow urine can be used to control the fungi. With the help of cow urine its dietary consequence was similarly confirmed with Golden wheat.

Nagamma et al., (2019) were reported that cow urine at $15 \%$ concentration proved to be effective to control powdery mildew on cucurbit. Successful controlled for the powdery mildew of cucurbit, spraying of $20 \%$ to $25 \%$ Butter milk is useful. Similarly, $20 \%$ ash spray also found to be successful to control the growth of powdery mildew of cucurbits.

The growth of Erysiphe cichoracearum and Sphaerotheca fuliginea, is inhibited by the spraying of Dashparni ark, a bi-product of plant and animal at $10 \%$ concentration. 
Table.1 Mycelial growth inhibition of Aspergillus flavus by different concentration of cow urine in potato broth culture media

\begin{tabular}{|c|c|c|c|c|c|c|c|c|c|c|c|c|}
\hline \multirow[b]{2}{*}{$\begin{array}{l}\text { Concentrations } \\
\text { (in \%) }\end{array}$} & \multicolumn{6}{|c|}{ Cow urine } & \multicolumn{6}{|c|}{ Goat urine } \\
\hline & $\begin{array}{l}\text { Control } \\
\text { (in gm) }\end{array}$ & $\begin{array}{c}\text { Fresh } \\
\text { weight } \\
\text { (in gm) }\end{array}$ & $\begin{array}{l}\text { Inhibition } \\
\text { (in \%) }\end{array}$ & $\begin{array}{l}\text { Control } \\
\text { (in gm) }\end{array}$ & $\begin{array}{c}\text { Dry } \\
\text { weight } \\
\text { (in gm) }\end{array}$ & $\begin{array}{l}\text { Inhibition } \\
\text { (in \%) }\end{array}$ & $\begin{array}{l}\text { Control } \\
\text { (in gm) }\end{array}$ & $\begin{array}{l}\text { Fresh } \\
\text { weight } \\
\text { (in gm) }\end{array}$ & $\begin{array}{l}\text { Inhibition } \\
\text { (in \%) }\end{array}$ & $\begin{array}{l}\text { Control } \\
\text { (in gm) }\end{array}$ & $\begin{array}{c}\text { Dry } \\
\text { weight } \\
\text { (in gm) }\end{array}$ & $\begin{array}{l}\text { Inhibition } \\
\text { (in \%) }\end{array}$ \\
\hline 5 & 6.919 & 6.110 & 11.667 & 2.374 & 2.077 & 12.522 & 6.988 & 6.049 & 13.416 & 2.407 & 2.036 & 15.455 \\
\hline 10 & 5.764 & 3.506 & 39.162 & 1.976 & 1.192 & 39.673 & 5.821 & 3.471 & 40.366 & 2.003 & 1.168 & 41.696 \\
\hline 25 & 5.190 & 2.445 & 52.504 & 1.746 & 0.831 & 52.573 & 5.242 & 2.420 & 53.445 & 1.770 & 0.815 & 54.163 \\
\hline 50 & 4.273 & 1.162 & 72.872 & 1.457 & 0.395 & 72.943 & 4.316 & 1.150 & 73.409 & 1.477 & 0.387 & 73.851 \\
\hline C.D. (at 5\%) & 0.598 & 0.480 & 9.976 & 0.182 & 0.163 & 4.136 & 0.604 & 0.476 & 9.778 & 0.185 & 0.160 & 3.997 \\
\hline SE(m) & 0.181 & 0.145 & 3.012 & 0.055 & 0.049 & 1.249 & 0.182 & 0.144 & 2.953 & 0.056 & 0.048 & 1.207 \\
\hline
\end{tabular}

Table.2 Mycelial growth inhibition of Aspergillus niger by different concentration of cow urine in potato broth culture media

\begin{tabular}{|c|c|c|c|c|c|c|c|c|c|c|c|c|}
\hline \multirow[b]{2}{*}{$\begin{array}{l}\text { Concentrations } \\
\text { (in \%) }\end{array}$} & \multicolumn{6}{|c|}{ Cow urine } & \multicolumn{6}{|c|}{ Goat urine } \\
\hline & $\begin{array}{l}\text { Control } \\
\text { (in gm) }\end{array}$ & $\begin{array}{c}\text { Fresh } \\
\text { weight } \\
\text { (in gm) }\end{array}$ & $\begin{array}{l}\text { Inhibition } \\
\text { (in \%) }\end{array}$ & $\begin{array}{l}\text { Control } \\
\text { (in gm) }\end{array}$ & $\begin{array}{c}\text { Dry } \\
\text { weight } \\
\text { (in gm) }\end{array}$ & $\begin{array}{l}\text { Inhibition } \\
\text { (in \%) }\end{array}$ & $\begin{array}{l}\text { Control } \\
\text { (in gm) }\end{array}$ & $\begin{array}{c}\text { Fresh } \\
\text { weight } \\
\text { (in gm) }\end{array}$ & $\begin{array}{l}\text { Inhibition } \\
\text { (in \%) }\end{array}$ & $\begin{array}{l}\text { Control } \\
\text { (in gm) }\end{array}$ & $\begin{array}{c}\text { Dry } \\
\text { weight } \\
\text { (in gm) }\end{array}$ & $\begin{array}{l}\text { Inhibition } \\
\text { (in \%) }\end{array}$ \\
\hline 5 & 5.864 & 5.216 & 11.042 & 2.052 & 1.773 & 13.584 & 5.922 & 5.163 & 12.803 & 2.081 & 1.738 & 16.481 \\
\hline 10 & 5.764 & 3.771 & 34.517 & 2.017 & 1.282 & 36.388 & 5.821 & 3.734 & 35.814 & 2.046 & 1.257 & 38.521 \\
\hline 25 & 5.190 & 2.665 & 48.416 & 1.817 & 0.906 & 49.890 & 5.242 & 2.638 & 49.437 & 1.842 & 0.888 & 51.570 \\
\hline 50 & 4.607 & 1.557 & 66.175 & 1.612 & 0.529 & 67.142 & 4.653 & 1.541 & 66.845 & 1.635 & 0.519 & 68.243 \\
\hline C.D. (at 5\%) & 0.494 & 0.179 & 5.618 & 0.173 & 0.061 & 5.458 & 0.498 & 0.177 & 5.507 & 0.175 & 0.06 & 5.275 \\
\hline SE $(\mathbf{m})$ & 0.149 & 0.054 & 1.696 & 0.052 & 0.018 & 1.648 & 0.151 & 0.054 & 1.663 & 0.053 & 0.018 & 1.593 \\
\hline
\end{tabular}


Table.3 Mycelial growth inhibition of Penicillium chrysogenum by different concentration of cow urine in potato broth culture media

\begin{tabular}{|c|c|c|c|c|c|c|c|c|c|c|c|c|}
\hline \multirow[b]{2}{*}{$\begin{array}{c}\text { Concentrations } \\
\text { (in \%) }\end{array}$} & \multicolumn{6}{|c|}{ Cow urine } & \multicolumn{6}{|c|}{ Goat urine } \\
\hline & $\begin{array}{l}\text { Control } \\
\text { (in gm) }\end{array}$ & $\begin{array}{c}\text { Fresh } \\
\text { weight } \\
\text { (in gm) }\end{array}$ & $\begin{array}{l}\text { Inhibition } \\
\text { (in \%) }\end{array}$ & $\begin{array}{l}\text { Control } \\
\text { (in gm) }\end{array}$ & $\begin{array}{c}\text { Dry } \\
\text { weight } \\
\text { (in gm) }\end{array}$ & $\begin{array}{l}\text { Inhibition } \\
\text { (in \%) }\end{array}$ & $\begin{array}{l}\text { Control } \\
\text { (in gm) }\end{array}$ & $\begin{array}{c}\text { Fresh } \\
\text { weight } \\
\text { (in gm) }\end{array}$ & $\begin{array}{l}\text { Inhibition } \\
\text { (in \%) }\end{array}$ & $\begin{array}{l}\text { Control } \\
\text { (in gm) }\end{array}$ & $\begin{array}{c}\text { Dry } \\
\text { weight } \\
\text { (in gm) }\end{array}$ & $\begin{array}{c}\text { Inhibition } \\
\text { (in \%) }\end{array}$ \\
\hline 5 & 5.184 & 4.766 & 8.089 & 1.814 & 1.620 & 10.715 & 5.236 & 4.718 & 9.909 & 1.840 & 1.588 & 13.709 \\
\hline 10 & 5.764 & 4.140 & 28.129 & 2.017 & 1.408 & 30.183 & 5.821 & 4.099 & 29.552 & 2.046 & 1.379 & 32.524 \\
\hline 25 & 4.803 & 2.755 & 42.676 & 1.681 & 0.937 & 44.314 & 4.851 & 2.727 & 43.811 & 1.704 & 0.918 & 46.181 \\
\hline 50 & 4.607 & 1.591 & 65.453 & 1.612 & 0.541 & 66.440 & 4.653 & 1.575 & 66.137 & 1.635 & 0.530 & 67.566 \\
\hline C.D. (at 5\%) & 0.241 & 0.305 & 5.178 & 0.085 & 0.104 & 5.03 & 0.243 & 0.302 & 5.075 & 0.086 & 0.102 & 4.861 \\
\hline SE $(m)$ & 0.073 & 0.092 & 1.563 & 0.026 & 0.031 & 1.519 & 0.073 & 0.091 & 1.533 & 0.026 & 0.031 & 1.468 \\
\hline
\end{tabular}


Antifungal efficacy of cow urine against Colletotrichum capsici isolated from anthracnose of chilli (Capsicum annuum L.). Different concentrations of cow urine $(5,10$ and $15 \%$ ) was determine the antifungal activity in poisoned food technique. Concentration dependent inhibitory activity of cow urine was found to display against fungal growth.

At $5 \%$ concentration indicating $>50 \%$ of an inhibition, Eco-friendly approaches for controlling of anthracnose in chilli, the use of cow urine can be cost effective (Kambar et al., 2013).

The urine of cow/goat were found to possess antifungal activity against mycotoxins producing fungi through poisoned food technique. Current research prove that active components of cow urine inhibits the germination of mycelial growth, it also inhibits the vegetative and reproductive phase of fungi. It is used for controlling of seedborne diseases as seed treatment agent. The goat urine has more antimicrobial properties because they eat lots of medicinal plants.

Components of medicinal plants in goat urine showed antimicrobial properties i.e. inhibits the mycelial growth of fungus and prevented them from mycotoxins production.

\section{Acknowledgement}

I am grateful, indebted and fortunate enough to get constant encouragement, motivation and guidance from my supervisor and teachers of Plant Biotechnology Laboratory (Department of Genetics and Plant Breeding) and B.Sc. (Ag.) Laboratory, Rajiv Gandhi South Campus, B.H.U., Barkachha, Mirzapur, U.P., who supported me a lot during the research work. Also, I would like to outspread my sincere esteems to all staff in laboratory for their timely support.

\section{References}

Craufurd, P. Q., Prasad, P. V. V., Waliyar, F., $\&$ Taheri, A. Drought, pod yield, preharvest Aspergillus infection and aflatoxin contamination on peanut in Niger. Field Crops Research, 98(1), 20-29, 2006.

Darwin C. H. L., PavithraIyanraj S., Jaiganesh V., Sutha Raja Kumar R. and Thamarai Selvi M., Effect of bio products and bio inoculants against Pyriculariagrisea the incitant of blast disease in rice. Plant Archives 20(Suppl. 2), 1440-1443, 2020.

Dharmaputra, O. S., Control of aflatoxigenic Aspergillus flavus in peanuts using nonaflatoxigenic A. flavus, A. niger and Trichoderma harzianum. BIOTROPIA-The Southeast Asian Journal of Tropical Biology, (21), 3244, 2003.

FAO., FAO statistical database. FAO, Rome, Italy. http://www.fao.org/faostat, 2017.

Ghosh Tanmay and Biswas M. K., Evaluation of Antibacterial and Antifungal Activity of Cow Urine against Some Seed Borne Microflora. Int.J.Curr.Microbiol.App.Sciences7(5), 1714-1727, 2018.

Ghosh, T., Biswas, M. K., \& Guin, C., Efficacy of cow urine in wheat (Triticum aestivum) production as plant growth promoter and antifungal agent. Journal of Pharmacognosy and Phytochemistry, 7(3), 485-493, 2019.

Kambar, Y., Vivek, M. N., Manasa, M., Prashith, K. T. R., \& Noor, N. A. S., Inhibitory effect of cow urine against Colletotrichumcapsici isolated from anthracnose of chilli (Capsicum annuum L.). Science, Technology and Arts Research Journal, 2(4), 91-93, 2013.

Kumar S., Sinha, A., Hooda, K. S. and Singh, V., Advanced detection techniques of 
toxigenic fungi and their management strategies. In: Sixth IJAA-JSPS, International conference on Contemporary Advances of Science and Technology, 7-9 Aug., BHU, Varanasi p.145, 2015a.

Kumar S., Sinha, A., Singh, S., Lingwal, S., Hooda, K. S. and Singh, V., Impact of climate change on mycotoxicogenic fungi of maize (Zea mays L.) In: National Symposium-cum-Mid Eastern Zonal Meeting of IPS on ICCPMI, 1819 Dec. pp. 40-41, 2015c.

Mausch, Kai, Alastair Orr, and B. Paige Miller. Targeting resilience and profitability in African smallholder agriculture: Insights from ICRISATled research programs., 545-558, 2017.

Modi, K. G., Sodhaparmar, H. R., Jacob, F., \& Patel, P., Use of urine and dung samples of cow and goat for biological control of phytopathogenic fungus Colletrotrichum falcatum. Int $J$ Sci Environ Technol, 6, 1679-1684, 2017.

Nagamma, G., Vijayalakshmi, G., Sanjay, M. T., Basha, C. J., Mallikarjuna, N., \& Sharif, M., A Review on Eco-Friendly Natural Plant and Animal Products for Plant Diseases Management. Int. J. Curr. Microbiol. App. Sci, 8(8), 19571977, 2019.

Ojiewo, C. O., Janila, P., Bhatnagar-Mathur, P., Pandey, M. K., Desmae, H., Okori, P., and Akpo, E. 2020. Advances in crop improvement and delivery research for nutritional quality and health benefits of groundnut (Arachis hypogaea L.). Frontiers in Plant Science, 11, 29.

Prakash, N., \& Sinha, A. P., In vitro studies of inhibitory activity of plant extracts and cow urine on mycelial growth of stem rot, Sclerotiumoryzae of rice. Journal of Applied and Natural Science, 9(1), 24-28, 2017.

Raghavendra, S. N., Raghu, H. S., Chaithra, C., \& Rajeshwara, A. N., Potency of Mancozeb Conjugated Silver Nanoparticles Synthesized from Goat, Cow and Buffalo Urine Against Colletotrichum gloeosporioides Causing Anthracnose Disease. Nature Environment \& Pollution Technology, 19(3), 969-979, 2020.

Shahbandeh M., Leading producers of peanuts worldwide 2018. Oct 13, Retrievedhttps://www.statista.com/statistics/103 0846/major-producers-of-peanutworldwide/, 2020.

Thamamarai S. M, Kurucheve V., Darwin Christdhas Henry 1., Sutha Raja Kumar R. and Jaiganesh V., Effect of animal excreta on mycelial growth of Pyricularia oryzae. Journal of Pharmacognosy and Phytochemistry, 8(3), 3373-3375, 2019.

Vincent, J. M., The esters of 4-hydroxy benzoic acid and related compounds, I. Methods for the study of their fungistatic properties. J. Soc. Chem. Ind. Landan.16: 746-755, 1947.

\section{How to cite this article:}

Sonam Kumari, Shrvan Kumar, Vishal Srivashtav and Pardeep Kumar. 2021. Effect of Cow and Goat Urine against Dominant Myco-Toxin Producing Fungi. Int.J.Curr.Microbiol.App.Sci. 10(06): 309-317. doi: https://doi.org/10.20546/ijcmas.2021.1006.033 